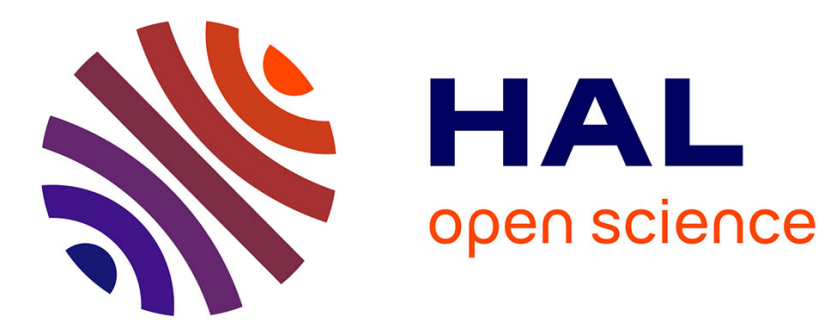

\title{
Metabolism of lactose and citrate by mutants of Lactococcus lactis producing excess carbon dioxide
}

\author{
A. El Attar, Christophe C. Monnet, Georges Corrieu
}

\section{To cite this version:}

A. El Attar, Christophe C. Monnet, Georges Corrieu. Metabolism of lactose and citrate by mutants of Lactococcus lactis producing excess carbon dioxide. Journal of Dairy Research, 2000, 67, pp.571-583. hal-02694413

\section{HAL Id: hal-02694413 \\ https: / hal.inrae.fr/hal-02694413}

Submitted on 1 Jun 2020

HAL is a multi-disciplinary open access archive for the deposit and dissemination of scientific research documents, whether they are published or not. The documents may come from teaching and research institutions in France or abroad, or from public or private research centers.
L'archive ouverte pluridisciplinaire HAL, est destinée au dépôt et à la diffusion de documents scientifiques de niveau recherche, publiés ou non, émanant des établissements d'enseignement et de recherche français ou étrangers, des laboratoires publics ou privés. 
Metabolism of lactose and citrate by mutants of Lactococcus lactis producing excess carbon dioxide

5

Shortened title: Lactose and citrate metabolism

\section{Corresponding author:}

Christophe MONNET

15 INRA, Laboratoire de Génie et Microbiologie des Procédés Alimentaires, 78850 Thiverval-Grignon, France

TEL: ++ 33 (0) 130815491

FAX: ++ 33 (0) 130815597

E-mail: monnet@platon.grignon.inra.fr 
SUMMARY. Mutants of Lactococcus lactis producing excess carbon dioxide could be isolated on LDHA-20 agar (El Attar et al., submitted for publication). The use of these mutants in the manufacture of Roquefort cheese could potentially improve the formation of openings in this cheese. The aim of this work was to examine the stability of these mutants, their enzymatic activities, as well as their metabolism of lactose and citrate when growing in milk. They produced less L-lactate than the parental strain and their lactate dehydrogenase activity was lower. Nevertheless none of the mutants produced no L-lactate at all and the most active gas generators among them generally produced 30-50 mM L-lactate. Unexpectedly, all the strains produced some D-lactate, some of them producing more than $10 \mathrm{mM}$. We observed that carbon dioxide production by the mutants could be determined indirectly by assaying acetoin, citrate and 2,3-butanediol by high performance liquid chromatography. Generally, spontaneous mutants were more stable than those obtained after treating with nitrosoguanidine or UV irradiation. 
Leuconostoc strains are widely used to manufacture Roquefort cheese (Devoyod \& Muller, 1969). Their main function is the production of a large quantity of carbon dioxide, required for the formation of the typical openings of this cheese. When grown in milk, leuconostocs produce carbon dioxide from lactose and citrate. Strains of Lactococcus lactis subsp. lactis biovar. diacetylactis can produce some carbon dioxide, but this occurs only when citrate is present in the medium. Their use instead of leuconostocs leads to cheeses with insufficient openings (J.-P. Reverbel, personal communication). Carbon dioxide is produced by $L$ c. $l$. l. diacetylactis during the conversion of citrate to pyruvate, and of pyruvate to acetoin. In the presence of citrate, acetoin is synthesized because the conversion of all the pyruvate to lactate would lead to excess production of NAD with respect to the available quantity of NADH. In the absence of citrate, strains of Lc. l. l. diacetylactis form primarily lactate from lactose. Lactate dehydrogenase (LDH)-deficient mutants of Lc. lactis, however, transform a part of the lactose to acetoin, leading to production of large quantities of carbon dioxide (McKay \& Baldwin, 1973). The use of this type of mutant could improve the opening of Roquefort cheese. In prior work, we selected mutants of Lc. l. l. diacetylactis producing excess carbon dioxide following mutagen treatments with nitrosoguanidine, UV radiation and also by spontaneous mutation (El Attar et al., submitted for publication). The aim of this work was to examine the metabolism of lactose and citrate of the mutants when growing in milk, as well as their stability and their LDH activity. 


\section{MATERIALS AND METHODS}

\section{Strains used and culture conditions}

Lactococcus lactis subsp. lactis biovar diacetylactis RD311 was obtained from Texel (F-86220 Dangé Saint Romain, France). Mutants producing excess carbon dioxide were isolated from strain RD311 as described elsewhere (El Attar et al., submitted for publication). Skimmed ewes milk powder was obtained from the Société des Caves (F-12250 Roquefortsur-Soulzon, France). It contained $407.6 \mathrm{~g}$ lactose and $439.5 \mathrm{~g}$ total protein per $\mathrm{kg}$. After a $24 \mathrm{~h}$ preculture at $30^{\circ} \mathrm{C}$ in $5 \mathrm{ml}$ of M17 broth (Terzaghi \& Sandine, 1975), the parental strain and mutants were inoculated at a concentration of $1 \%$ in $20 \mathrm{ml}$ of reconstituted skimmed ewes milk $(130 \mathrm{~g} / \mathrm{l})$ that had been sterilized at $110^{\circ} \mathrm{C}$ for $15 \mathrm{~min}$. Cultures were run in sealed vessels that were perfectly airtight, for $24 \mathrm{~h}$ at $30^{\circ} \mathrm{C}$ as previously described (El Attar et al., submitted for publication). The stability of mutants was studied by carrying out successive transfers of the preculture at an inoculation concentration of $1 \%$. The $20^{\text {th }}$ successive subculture was used to prepare a culture in milk as described above.

\section{Analyses}

Substrates and metabolites were assayed in non-inoculated milk, as well as after $24 \mathrm{~h}$ of culture. The $\mathrm{CO}_{2}$ produced by the cultures was assayed using the method of Kihal (1995) as modified by El Attar et al. (submitted for publication). D-lactate, L-lactate and ethanol were assayed with Boehringer kits (Mannheim, Germany). Diacetyl and $\alpha$-acetolactate were assayed with the method of Mohr et al. (1997).

Lactose, citrate, acetate, formate, acetoin and 2,3-butanediol were assayed by high performance liquid chromatography (HPLC) as described by Bassit et al. (1993). Isovaleric acid was used as internal standard at a final concentration of $2.5 \mathrm{~g} / \mathrm{l}$. The retention times of 
acetoin, as well as the meso, D and L isomers of 2,3-butanediol were very close in this assay. Unlike 2,3-butanediol, acetoin absorbs at $215 \mathrm{~nm}$ and so was assayed with a UV detector (Waters model 410, Milford, MA. 01757, USA). 2,3-Butanediol was assayed with a Waters Model 410 refractometer. The refractometry peak contained both acetoin and 2,3-butanediol, but the latter could be deduced because the quantity of the former was known (assay of acetoin at $215 \mathrm{~nm}$ ). Lactose, acetate and formate were assayed by refractometry and citrate was assayed with the UV detector.

Occasionally, the sum of D- and L-lactate was also measured using a colorimetric method. Five hundred microliters of trichloroacetic acid ( $3 \mathrm{M}$ ) were added to $500 \mu \mathrm{l}$ of a milk sample. After an incubation for $15 \mathrm{~min}$ at $4^{\circ} \mathrm{C}, 500 \mu \mathrm{l}$ of $\mathrm{NaOH}(3 \mathrm{M})$ were added and the sample was centrifuged for $10 \mathrm{~min}$ at $10,000 \mathrm{~g}$. The supernatant was then diluted 25 times in distillated water, and treated with copper and calcium as described by Barker (1957) to remove interfering substances. The sum of D- and L-lactate was then measured as described by Taylor (1996).

\section{Assays of Enzymatic Activities}

Cells cultivated for $24 \mathrm{~h}$ at $30^{\circ} \mathrm{C}$ in $100 \mathrm{ml}$ of $\mathrm{M} 17$ broth were harvested by centrifugation at $14,000 \mathrm{~g}$ at $4^{\circ} \mathrm{C}$ for $15 \mathrm{~min}$. After cells were washed with $20 \mathrm{ml}$ of $50 \mathrm{mM}$ sodium phosphate buffer $(\mathrm{pH} 7)$, they were resuspended in $1 \mathrm{ml}$ of the same buffer and placed in a $2 \mathrm{ml}$ tube containing $600 \mathrm{mg}$ of $0.1 \mathrm{~mm}$ diameter glass beads (PolyLabo, F-67000 Strasbourg, France). Cells were then disrupted in a cell disruptor (FP120 FastPrep ${ }^{\mathrm{TM}}$; Savant Instruments Inc., Holbrook, NY 11741, USA) for $30 \mathrm{~s}$ at $4^{\circ} \mathrm{C}$ at speed 6.5. After centrifugation for $5 \mathrm{~min}$ at $21,000 \mathrm{~g}$ and $4^{\circ} \mathrm{C}$, enzymatic activities were determined in the supernatant. Lactate dehydrogenase was measured by monitoring the decrease in absorbance at $340 \mathrm{~nm}$. The assay was performed in $50 \mathrm{mM}$ Tris-maleate buffer (pH 7) containing $10 \mathrm{mM}$ 
sodium pyruvate, $1 \mathrm{mM}$ fructose-1,6-diphosphate and $0.15 \mathrm{mM}$ NADH (Thomas, 1976). These enzyme activities were corrected for NADH oxidase activities, determined in the same conditions, but in the absence of pyruvate. One enzyme unit was defined as $1 \mu$ mol of NADH oxidized/min. Protein concentrations were determined with the method of Bradford (1976) using bovine serum albumin as a protein standard.

\section{$16 S$ rDNA sequencing}

Strains were inoculated on MRS agar plates (De Man et al. 1960). After 2 days of culture at $30^{\circ} \mathrm{C}$, one colony of each strain was selected, and its DNA was extracted using the

10 GeneReleaser $^{\mathrm{TM}}$ system (ATGC biotechnologie, Croissy-Beaubourg, France). The almost complete $16 \mathrm{~S}$ rDNA gene was amplified by PCR, and its partial sequence was determined using the sequencing primers SP3, SP4 and SP5, as described by Cibik et al. (2000). The overlapping sequences were then merged, and the resulting sequence was compared with those listed in the Ribosomel Database Project (RDP, http://www.cme.msu.edu/RDP) (Cibik et al., 2000). 


\section{RESULTS}

\section{Substrate consumption and metabolite production}

Mutants producing excess $\mathrm{CO}_{2}$ that were isolated from Lc. l. l. diacetylactis RD311 in prior work (El Attar et al., submitted for publication) were grown for $24 \mathrm{~h}$ in ewes milk. Only mutants producing more than $45 \mathrm{mM} \mathrm{CO}_{2}$ were used in the study. Four of them were spontaneous, 25 were obtained by UV irradiation, and 38 and 28 were obtained by treatment with 20 and $200 \mu \mathrm{g} / \mathrm{ml}$ of nitrosoguanidine (NTG). For each type of mutant, Table 1 shows mean values of substrates consumed and metabolites produced.

Consumption of substrates. The parental strain exhausted all available citrate (initial concentration $10.0 \mathrm{mM}$ ) in the milk, and about $25 \%$ of the lactose (initial concentration 145 $\mathrm{mM})$. Mean citrate consumption by the different types of mutants was very close to that of the parental strain. Mean lactose consumption by the mutants ranged between $83 \%$ (mutants obtained with $200 \mu \mathrm{g} / \mathrm{ml}$ of NTG) and 106\% (mutants obtained with $20 \mu \mathrm{g} / \mathrm{ml}$ of NTG) of that of the parental strain.

$D$ - and L-lactate production. The parental strain produced primarily L-lactate, accounting for $86 \%$ of the metabolites produced (as $\mathrm{mM}$ carbon). This percentage decreased to $43 \%$ for spontaneous mutants, and to 29,28 and $32 \%$ for mutants obtained with $20 \mu \mathrm{g} / \mathrm{ml}$

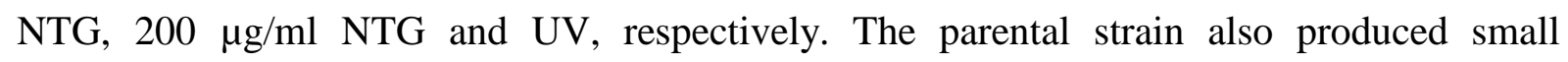
quantities of D-lactate, $1.2 \%$ of total lactate production, while this figure was much higher for the mutants. The mutants producing the highest amounts of D-lactate generally produced between 20 and $50 \mathrm{mM}$ L-lactate (Fig. 1). Additional experiments were performed to make sure that the observed production of D-lactate was not due to contamination of cultures or an experimental error in the assay of D-lactate. Mutant A69 produced $8.8 \mathrm{mM}$ of D-lactate $(\mathrm{SD}=$ 
$0.21 \mathrm{mM})$ and $24.5 \mathrm{mM}$ of L-lactate $(\mathrm{SD}=0.9 \mathrm{mM})$. After $24 \mathrm{~h}$ of growth of mutant A69 in milk, the culture was diluted 100 times in isotonic saline $(9 \mathrm{~g} / \mathrm{l} \mathrm{NaCl})$ and dispersed with a mechanical blender (Ultra-Turrax ${ }^{\circledR}$ model T25; Ika Labortechnik, D-79217 Staufen, Germany) for $1 \mathrm{~min}$. The cells were then inoculated on MRS agar plates (De Man et al. 1960) to obtain about 100 colonies per Petri dish. After 2 days of culture at $30^{\circ} \mathrm{C}, 200$ individual colonies were randomly picked and tested for their identity as described below. When cultivated at $30^{\circ} \mathrm{C}$, all the isolates had the following properties (except when stated, all cultures on agar plates where incubated for 2 days before examination) : Gram-positive, coccishaped and catalase negative microorganisms; blue colonies formed on Kempler \& McKay agar (1980); brown colonies formed on LDHA-20 agar (El Attar et al., submitted for publication); arginine positive on M16-BCP agar (Thomas, 1973); absence of growth on M17 agar supplemented with $65 \mathrm{~g} / \mathrm{l} \mathrm{NaCl}$; growth on M17 agar supplemented with $20 \mathrm{~g} / \mathrm{l} \mathrm{NaCl}$; fermentation of lactose, galactose, fructose, maltose and ribose when tested on a modified MRS agar in which glucose and citrate were omitted, and containing $5 \mathrm{~g} / \mathrm{l}$ of the sugar substrate and $0.05 \mathrm{~g} / \mathrm{l}$ of bromocresol purple; absence of growth on MRS agar supplemented with $20 \mu \mathrm{g} / \mathrm{ml}$ vancomycin. All the isolates grew on M17 agar when incubated for 7 days at $10^{\circ} \mathrm{C}$ or for 2 days at $40^{\circ} \mathrm{C}$. None of the isolates grew on M17 agar at $45^{\circ} \mathrm{C}$. Except the ability to form brown colonies on LDHA-20 agar, all these properties were also observed when the parent strain was examinated. Furthermore, partial 16S rDNA sequences of strain RD311 and mutant A69, were closely related to the sequence of Lc. lactis IL 1403 (homology of 99.6 and $99.0 \%$, respectively), confirming their classification as Lc. lactis. Hence no contamination could be detected in the culture of mutant A69. We have also checked that the D-LDH present in the Boehringer kits for the assay of D-lactate was not contaminated with L-LDH, as there was no increase of NADH concentration in the presence of L-lactate. Several other metabolites that can be produced by lactic acid bacteria (ethanol, acetate, carbon dioxide, 
acetoin, 2,3-butanediol, formate and succinate) did not lead to an increase of the NADH concentration during the assay of D-lactate with the Boehringer kits. Furthermore, the total production of D- and L- lactate, as measured by the colorimetric method of Taylor (1996), by HPLC with UV detection, and by HPLC with refractometer detection, were 34.8 (SD = 1.67 $\mathrm{mM}), 32.5(\mathrm{SD}=1.24 \mathrm{mM})$ and $34.0(\mathrm{SD}=0.82 \mathrm{mM})$, respectively. These values were not significantly different from the sum of the production of D- and L- lactate measured with the Boehringer kit $(33.3 \mathrm{mM})$. Hence, we could detect no experimental error in the assay of Dlactate.

Acetate production. Mean acetate production by the mutants was lower than that of the parental strain (Table 1). When citrate is consumed by lactococci, there is an equivalent production of acetate by citrate lyase. Acetate may also be produced by lactococci via an acetate kinase. Thus, its production by lactococci should theoretically be higher than or equal to citrate consumption. Surprisingly, mean acetate production by the mutants was lower than citrate consumption. This was also the case for most mutants when considered individually (results not shown). We may thus conclude that most mutants consumed part of the acetate produced via citrate lyase.

Production of ethanol, formate, acetoin and 2,3-butanediol. In contrast to the parental strain, the mutants produced ethanol and formate (Table 1). Acetoin and 2,3-butanediol production was also higher. We could not detect significant production of $\alpha$-acetolactate or diacetyl in any of the cultures.

$\mathrm{CO}_{2}$ production. The parental strain produced $18 \mathrm{mM}$ of $\mathrm{CO}_{2}$. Mean $\mathrm{CO}_{2}$ production was respectively 3.5, 4.8, 4.0 and 4.6 times higher for spontaneous mutants, mutants obtained with $20 \mu \mathrm{g} / \mathrm{ml}$ of NTG, $200 \mu \mathrm{g} / \mathrm{ml}$ of NTG, and UV. Some mutants produced almost $120 \mathrm{mM}$, but unexpectedly $\mathrm{CO}_{2}$ production by the mutants did not tend to vary inversely with their Llactate production (Fig. 2). However, the mutants producing the highest amounts of $\mathrm{CO} 2$ often 
produced between 30 and $50 \mathrm{mM}$ L-lactate. When lactose and citrate are metabolized, $\mathrm{CO}_{2}$ can arise from the action of oxaloacetate decarboxylase (OAD), $\alpha$-acetolactate synthase (ALS), $\alpha$-acetolactate decarboxylase (ALDC) and pyruvate dehydrogenase (PDH). The quantity of $\mathrm{CO}_{2}$ produced by $\mathrm{OAD}$ is equal to citrate consumption, and that produced by ALS and ALDC is double the production of acetoin and 2,3-butanediol. If it is admitted that mutants producing little acetate transformed this compound to ethanol, then the quantity of $\mathrm{CO}_{2}$ produced by the action of $\mathrm{PDH}$ should be equal to acetate + ethanol - citrate - formate. The following equation should thus be theoretically verified:

$$
\mathrm{CO}_{2}=2 \times \text { acetoin }+2 \times 2,3 \text {-butanediol }+ \text { acetate }+ \text { ethanol }- \text { formate }
$$

The experimental results corresponding to equation (1) are shown in Fig. 3A. The differences between the measured values and those predicted with the theoretical relationship can be determined by calculating a relative error with the following formula:

$$
\text { Relative error }(\%)=\sqrt{\sum\left(\left(y_{p}-y_{m}\right) / y_{m}\right)^{2} / n} \times 100
$$

where $y_{p}$ is the predicted value, $y_{m}$ the measured value and $n$ the number of experimental points.

The dispersion of the points compared to the theoretical relationship was quite low (relative error $=10.4 \%$ ). The quantity of pyruvate consumed by PDH and PFL is equal to acetate + ethanol - citrate, and that consumed by PFL is equal to formate production. The mean value of acetate + ethanol - citrate was respectively 3.6, 17.9, 31.3, 28.4 and $26.5 \mathrm{mM}$ for the parental strain, spontaneous mutants, mutants obtained with $20 \mu \mathrm{g} / \mathrm{ml}$ of NTG, $200 \mu \mathrm{g} / \mathrm{ml}$ of NTG, and UV. These values were very close to the corresponding productions of formate (Table 1), indicating that the quantity of pyruvate consumed by PDH was low or null. The same result was obtained when the mutants were considered individually (relative error $=22.2 \%$ ). If we consider that PDH was not used, equation (1) becomes: 


$$
\mathrm{CO}_{2}=2 \times \text { acetoin }+2 \times 2,3 \text {-butanediol }+ \text { citrate }
$$

The experimental results corresponding to equation (2) are shown in Fig. 3B. The measured quantities of $\mathrm{CO}_{2}$ were generally very close to those predicted by equation (2). In addition, the relative error $(8.8 \%)$ was somewhat lower than in the case of equation (1).

Carbon balance. The differences between mean quantities of carbon consumed and carbon produced were relatively low for the parental strain and the four types of mutants (Table1). When each strain was examined individually, however, some of them exhibited differences approaching 20\% (results not shown).

Reoxidation of $N A D H$. The quantity of NADH that is reoxidized to NAD can be calculated in the basis of metabolite productions. Supposing that D-lactate is produced by an $\mathrm{LDH}$, the quantity of NADH consumed by enzymes with LDH activity is equal to the total production of D- and L-lactate. The quantity of NADH consumed by acetaldehyde dehydrogenase and alcohol dehydrogenase is equal to twice the production of ethanol, and that consumed by acetoin reductase is equal to the production of 2,3-butanediol. Based on these assumptions, the quantity of NADH reoxidized by lactate formation accounted for $99.4 \%$ of the total amount of NADH reoxidized by the parental strain. This value was respectively 57.5 , $39.5,39.0$ and $41.6 \%$ for the spontaneous mutants, mutants obtained with $20 \mu \mathrm{g} / \mathrm{ml}$ of NTG, $200 \mu \mathrm{g} / \mathrm{ml}$ of NTG, and UV. In contrast to the parental strain, the mutants reoxidized a large fraction of NADH via the formation of ethanol, and to a lesser extent by the formation of 2,3butanediol.

\section{Lactate dehydrogenase activity}


The LDH activity of the parent strain was $12.2 \mathrm{U} / \mathrm{mg}$, whereas it was between 0.003 and $5.8 \mathrm{U} / \mathrm{mg}$ for the mutants. Plotting LDH vs. the production of L-lactate shows that on average, LDH activity tended to increase with the production of L-lactate (Fig. 4).

\section{Stability of the mutants}

The stability of the mutants was determined by measuring their $\mathrm{CO}_{2}$ production in milk, both before and after 20 successive transfers in M17 broth. Regardless of the mutagen treatment applied, the mutants produced on average less $\mathrm{CO}_{2}$ after 20 successive transfers and also became more acidifying (Table 2). The percentage of stable mutants was determined by considering that the definition of a stable mutant is one whose $\mathrm{CO}_{2}$ production after the $20^{\text {th }}$ transfer is more than $80 \%$ of production after the first transfer, and if no white colonies appeared on LDHA-20 agar. Spontaneous mutants were more stable (50\% of the mutants) than those obtained by treating cells with $200 \mu \mathrm{g} / \mathrm{ml}$ of NTG (39\% of the mutants). The latter were more stable than the other types of mutants tested.

The lower carbon dioxide production after successive transfers in M17 broth may also be due to a poor growth of the mutants. This may be the case, for example, if the mutants had become proteinase-deficient or lactose-negative after the successive transfers. This is unlikely, however, since mutants having poor growth in milk would also be less acidifying, which is contrary to what we observed. Additional experiments were performed with mutant A400 in order to study its changes after the successive transfers. Mutant A400 formed brown colonies at the first transfer whereas the colonies were white after the $20^{\text {th }}$ transfer. Three separate milk cultures were performed after the first and the $20^{\text {th }}$ transfer. $\mathrm{CO}_{2}$ production, which was 56.0 $\mathrm{mM}(\mathrm{SD}=2.1 \mathrm{mM})$ after the first transfer, decreased to $29.0 \mathrm{mM}(\mathrm{SD}=0.7 \mathrm{mM})$ after the $20^{\text {th }}$ transfer. The final $\mathrm{pH}$ decreased from $5.05(\mathrm{SD}=0.01)$ to $4.72(\mathrm{SD}=0.01)$. The final 
population was $2.4 \times 10^{9} \mathrm{CFU} / \mathrm{ml}\left(\mathrm{SD}=0.2 \times 10^{9} \mathrm{CFU} / \mathrm{ml}\right)$ after the first transfer and it was $2.5 \times 10^{9} \mathrm{CFU} / \mathrm{ml}\left(\mathrm{SD}=0.2 \times .10^{9} \mathrm{CFU} / \mathrm{ml}\right)$ after the $20^{\text {th }}$ transfer. LDH activity, measured in a cell-free extract prepared after the first transfer, was $0.6 \mathrm{U} / \mathrm{mg}$, whereas it was $13.3 \mathrm{U} / \mathrm{mg}$ after the $20^{\text {th }}$ the transfer. Instability of this mutants was thus associated with an increase of LDH activity rather than poor growth after successive transfers.

We attempted to determine if the instability of the strains could be correlated with the profile of metabolite production in the first culture, since this could possibly enable us to predict stability of the mutants. The mean productions of $\mathrm{CO}_{2}$, acetate and 2,3-butanediol by stable mutants were similar (differences of about 10\%) to those of the unstable strains (Table 3). On the other hand, their productions of D-lactate, formate, acetoin and ethanol were lower, while that of L-lactate was higher (differences of 20-40\%). When strain instability is represented (expressed as relative variation of $\mathrm{CO}_{2}$ production) vs. their production of metabolites, it is also seen that the points corresponding to the stable strains are on average shifted to the right (L-lactate) or the left (D-lactate, formate, acetoin and ethanol) of those of the unstable strains. As an example, Fig. 5 shows the results for D-lactate. This type of representation, however, did not enable us to define the zones of metabolite concentrations of only the stable strains. 


\section{DISCUSSION}

We have examined the biochemical characteristics of Lc. l. l. diacetylactis RD311 mutants producing excess $\mathrm{CO}_{2}$. When grown in milk, the mutants produced less L-lactate and acetate than the parental strain, and produced more acetoin, 2,3-butanediol, ethanol, formate and D-lactate. In comparison to the parental strain, all the mutants had a lower LDH activity. It is of interest to note that the LDH-negative mutants described by McKay \& Baldwin (1973), Platteeuw et al. (1995), Gasson et al. (1996), as well as the mutants of the present work continued to produce L-lactate. One working hypothesis to explain this result is that the gene coding for L-LDH was not totally inactivated in the work cited. A second hypothesis is that Llactate could also have been produced by Lc. lactis by an enzyme other than L-LDH. In addition, strain RD311 produced small quantities of D-lactate and this production was higher in the mutants. The finding that D-lactate can be produced by lactococci is unusual and suggested that the cultures may be mixtures of Lactococcus and Leuconostoc strains. Indeed, it has been observed that lactococci are sometimes in close association with leuconostocs, probably due to a cell wall-mediated interaction (Gopal et al. 1996). However, most leuconostocs are able to grow in the presence of vancomycin (Orberg and Sandine, 1984), which was not the case of the parent strain and the mutants that we studied here (El Attar et al., submitted for publication). Furthermore, 16S rDNA sequence studies confirmed that the parent strain and mutant A69 belonged to Lc. lactis. We were thus unable to detect any contamination of our cultures.

As a result of their lower production of L-lactate, the mutants reoxidize a part of the NADH produced by glycolysis, by forming ethanol and 2,3-butanediol. In order to explain why most mutants produced less acetate than citrate consumed, we invoke the hypothesis according to which they transformed a part of the acetate arising from citrate to ethanol. This 
would enable them to reoxidize more NADH from citrate. Hols et al. (1999) demonstrated recently that LDH-deficient strains of Lc. lactis are able to convert acetate into ethanol.

The parental strain produced about $18 \mathrm{mM}$ of $\mathrm{CO}_{2}$ when cultured in ewes milk. This production resulted primarily from the utilization of citrate, since a citrate-negative plasmid variant selected from this strain produced no $\mathrm{CO}_{2}$ (results not shown). At the opposite end, some mutants produced up to $120 \mathrm{mM} \mathrm{CO}_{2}$. In contrast to expectations, $\mathrm{CO}_{2}$ production by the mutants did not tend to vary inversely with L-lactate production. The most active gas producing mutants, however, often produced 30 to $50 \mathrm{mM}$ L-lactate, equal to about one-third of L-lactate production by the parental strain. It is possible that the lower $\mathrm{CO}_{2}$ production by mutants producing less than $30 \mathrm{mM}$ L-lactate was due to their lower or slower growth. When attempts are made to obtain excess $\mathrm{CO}_{2}$ production by Lc. lactis strains, it is thus preferable to induce mutations that do not cause an excessive reduction in lactate production. The analysis of metabolites led to the conclusion that in our culture conditions, $\mathrm{CO}_{2}$ production via pyruvate dehydrogenase was negligible. This was predictable, since the mutants probably contained a high intracellular NADH concentration, and it is known that Lc. lactis pyruvate dehydrogenase is inhibited by NADH (Snoep et al. 1992). The mutants thus produced $\mathrm{CO}_{2}$ primarily via $\alpha$-acetolactate synthase, $\alpha$-acetolactate decarboxylase and to a lesser extent via oxaloacetate decarboxylase. As a result, $\mathrm{CO}_{2}$ production by the parental strain and the mutants can be calculated from the concentrations of citrate, acetoin and 2,3-butanediol. It should thus be possible to indirectly measure $\mathrm{CO}_{2}$ production by these strains during cheese manufacture by using the chromatographic technique described in Materials and Methods.

The instability of the mutants is probably due to a reversion of the mutations affecting LDH rather than a poor capacity to grow in milk, since these mutants became more acidifying after 20 successive transfers. This was confirmed in the case of mutant A400, whose LDH activity increased after successive transfers. In the present work, spontaneous mutants were 
more stable (50\% of them) than those obtained after treatment with NTG or UV. According to Neidhardt et al. (1990), spontaneous mutations are often deletions, but there is no spontaneous reversion in this case. This could explain our results, but unfortunately they are based only on the examination of four spontaneous mutants. It would thus be desirable to confirm our results with a larger number of mutants. In addition, and in contrast to the mutants obtained after the action of NTG or UV, spontaneous mutants probably have the advantage of not containing secondary mutations, which could affect the growth or technological properties of the strains. Even though the mean production of some metabolites by stable mutants differed from that of unstable mutants, we could not establish a correlation between the production of these metabolites and stability. If this were the case, it would have been possible to predict the stability of a mutant as a function of the concentrations of metabolites produced when grown in milk.

This work will be followed by the examination of the kinetics of acidification and $\mathrm{CO}_{2}$ production by certain stable mutants in pure cultures and in mixed cultures with acidifying lactococci. The relationship between the kinetics of acidification and of production of $\mathrm{CO}_{2}$ is probably very important in the formation of openings in cheese. In particular, it would be interesting to devise a culture device in which it would be possible to follow both the content of dissolved carbon dioxide and the amount of carbon dioxide released from the culture medium.

The authors thank A. Normand and G. Yonnet for their technical assistance, E. Lepage and P. Tailliez for the 16S rDNA analysis, and C. Trelea for helpful suggestions. A. El Attar is the recipient of a Franco-Egyptian cooperation fellowship from the French Foreign Affairs Ministry. 


\section{REFERENCES}

BARKER, S. B. 1957 In Methods in Enzymology, vol. 3, Preparation and colorimetric determination of lactic acid, pp. 241-246 (Eds. S.P. Colowick \& N.O. Kaplan) New York: Academic press inc.

Bassit, N., Boquien, C. Y., Picque, D. \& Corrieu, G. 1993 Effect of initial oxygen concentration on diacetyl and acetoin production by Lactococcus lactis subsp. lactis biovar diacetylactis. Applied and Environmental Microbiology 59 1893-1897

Boumerdassi, H., Monnet, C., Desmazeaud, M. \& Corrieu, G. 1997 Isolation and properties of lactococcus lactis subsp. lactis biovar diacetylactis CNRZ 483 mutants producing diacetyl and acetoin from glucose. Applied and Environmental microbiology 63 2293-2299

BRADFORD, M. M. 1976 A rapid and sensitive method for the quantitation of microgram quantities of protein utilizing the principle of protein-dye binding. Analytical Biochemistry $\mathbf{7 2}$ $248-254$

CiBIK, R., LePAGE, E. \& TAILlIEZ, P. 2000 Molecular diversity of Leuconostoc mesenteroides and Leuconostoc citreum isolated from traditional french cheeses as revealed by RAPD fingerprinting, 16S rDNA sequencing and 16S rDNA fragment amplification. Systematic and Applied Microbiology (in press)

De Man, J. C., Rogosa, M. \& Sharpe, M. E. 1960 A medium for cultivation of lactobacilli. Journal of Applied Bacteriology 23 130-135

Devoyod, J. J. \& MulleR, M. 1969 [The microbial flora of Roquefort cheese III. The lactic streptococci and the leuconostocs. Influence of different contamination microorganisms.] Lait 487 369-399 
El Attar, A., Monnet, C., Aymes, F., Corrieu, G. A method for the selection of Lactococcus lactis mutants producing excess carbon dioxide. Submitted for publication in the Journal of Dairy Research

Gasson, M. J., Benson, K., Swindell, S. \& GRIFFIn, H. 1996 Metabolic engineering of the

Lactococcus lactis diacetyl pathway. Lait 76 33-40

Gopal, P. K., Davey, G. P., Crow, V. L., Pillidge, C. J., Coolbear, T. \& Holland, R. 1996 Extracellular material from Leuconostoc mesenteroides subsp. dextranicum mediates the aggregation of lactococcal cells : implications for the isolation of single strains. Journal of Applied Bacteriology $\mathbf{8 1} 48-56$

10 Hols, P., Ramos, A., Hugenholtz, J., Delcour, J., DeVos, W. M., Santos, H. \& KLEEREBEZEM, M. 1999 Acetate utilization in Lactococcus lactis deficient in lactate dehydrogenase: a rescue pathway for maintaining redox balance. Journal of Bacteriology 181 $5521-5526$

KEMPLER, G. M. \& MCKAY, L. L. 1980 Improved medium for detection of citrate-fermenting Streptococcus lactis subsp. diacetylactis. Applied and Environmental Microbiology 39 926927

KIHAL, M. 1995 [Study of the carbon dioxyde production by Leuconostoc mesenteroides, Application to blue-veined cheese technologies] $\mathrm{PhD}$ thesis, University Es-Senia, Oran, Algeria

MC KAY, L. L. \& BALDwin, K. A. 1973 Altered metabolism in a Streptococcus lactis C2 mutant deficient in lactic dehydrogenase. Journal of Dairy Science 57 181-186 Mohr, B., Aymes, F., Rea, M. C., Monnet, C. \& Cogan, T. M. 1997 A new method for the determination of 2-acetolactate in dairy products. International Dairy Journal 7 701-706 Neidhardt, F. C., Ingraham, J. L. \& Schaechter, M. 1990 In Physiology of the bacterial cell, A molecular Approach. Sunderland, Massachusetts: Sinauer Associates, Inc. 
ORBERG, P. K. \& SANDINE, W. E. 1984 Common occurence of plasmid DNA and vancomycin resistance in Leuconostoc spp. Applied and Environmental Microbiology 48 1129-1133

Platteeuw, C., Hugenholtz, J., Starrenburg, M., Van Alen-Boerrigter, I. \& De Vos, W. M. 1995 Metabolic engineering of Lactococcus lactis: influence of the overproduction of $\alpha$-acetolactate synthase in strains deficient in lactate dehydrogenase as a function of culture conditions. Applied and Environmental Microbiology 61 3967-3971

Snoep, J. L., Teixeira de Mattos, M. J., Starrenburg, M. J. C. \& Hugenholtz, J. 1992 Isolation, characterization, and physiological role of the pyruvate dehydrogenase complex and $\alpha$-acetolactate synthase of Lactococcus lactis subsp. lactis bv. diacetylactis. Journal of Bacteriology 174 4838-4841

TAYLOR, K. A. C. C. 1996 A simple colorimetric assay for muramic acid and lactic acid. Applied Biochemistry and Biotechnology 56 49-58

TerZaghi, B. E. \& SAndine, W. E. 1975 Improved medium for lactic streptococci and their bacteriophages. Applied Microbiology 29 807-813

Thomas, T. D. 1973 Agar medium for differentiation of Streptococcus cremoris from other bacteria. New Zealand Journal of Dairy Science \& Technology 8 70-71

Thomas, T. D. 1976 Regulation of lactose fermentation in group N streptococci. Applied and Environmental Microbiology 32 474-478 


\section{FIGURE LEGENDS}

Fig. 1. Production of D-lactate as a function of L-lactate production. $24 \mathrm{~h}$ cultures of the parental strain $(\bullet)$, of spontaneous mutants $(O)$ and of mutants obtained with $20 \mu \mathrm{g} / \mathrm{ml}$ of

$5 \quad \mathrm{NTG}(\Delta), 200 \mu \mathrm{g} / \mathrm{ml}$ of NTG $(\square)$, and UV irradiation $(\diamond)$.

Fig. 2. $\mathrm{CO}_{2}$ production as a function of L-lactate production. $24 \mathrm{~h}$ cultures of the parental strain (•), of spontaneous mutants (O) and of mutants obtained with $20 \mu \mathrm{g} / \mathrm{ml}$ of NTG $(\Delta)$, $200 \mu \mathrm{g} / \mathrm{ml}$ of NTG $(\square)$, and UV irradiation $(\diamond)$.

10

Fig. 3. Quantities of $\mathrm{CO}_{2}$ measured vs. the calculated quantities of $\mathrm{CO}_{2}$. Calculated $\mathrm{CO}_{2}=2 \mathrm{x}$ acetoin $+2 \times 2$,3-butanediol + acetate + ethanol - formate $(A)$ and calculated $\mathrm{CO}_{2}=2 \mathrm{x}$ acetoin $+2 \times 2$,3-butanediol + citrate (B). $24 \mathrm{~h}$ cultures of the parental strain $(\bullet)$, of spontaneous mutants $(\mathrm{O})$ and of mutants obtained with $20 \mu \mathrm{g} / \mathrm{ml}$ of NTG $(\Delta), 200 \mu \mathrm{g} / \mathrm{ml}$ of NTG ( $\square)$, and UV irradiation $(\diamond)$.

Fig. 4. Lactate dehydrogenase (LDH) activity as a function of L-lactate production. $24 \mathrm{~h}$ cultures of the parental strain $(\bullet)$, of spontaneous mutants $(O)$ and of mutants obtained with $20 \mu \mathrm{g} / \mathrm{ml}$ of NTG $(\Delta), 200 \mu \mathrm{g} / \mathrm{ml}$ of NTG $(\square)$, and UV irradiation $(\diamond)$.

Fig. 5. Changes in $\mathrm{CO}_{2}$ production by the mutants after 20 successive transfers of preculture vs. their D-lactate production after the first transfer. Mutants considered as stable $(\bullet)$ or unstable $(\mathrm{O}) . \mathrm{T}_{1}$ and $\mathrm{T}_{20}$ represent respectively the first and the $20^{\text {th }}$ transfer. 
Fig. 1

10

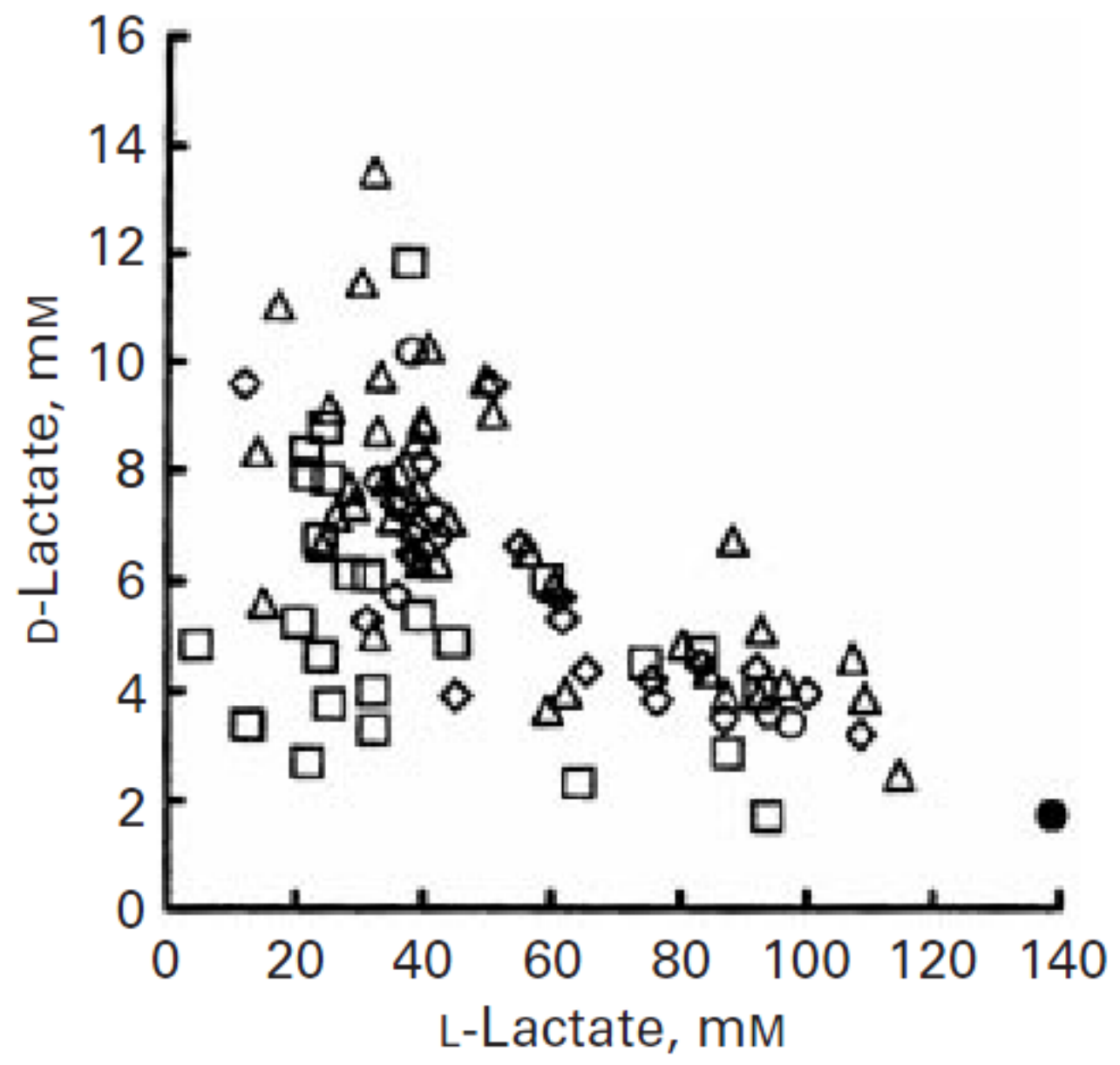


Fig.2

10

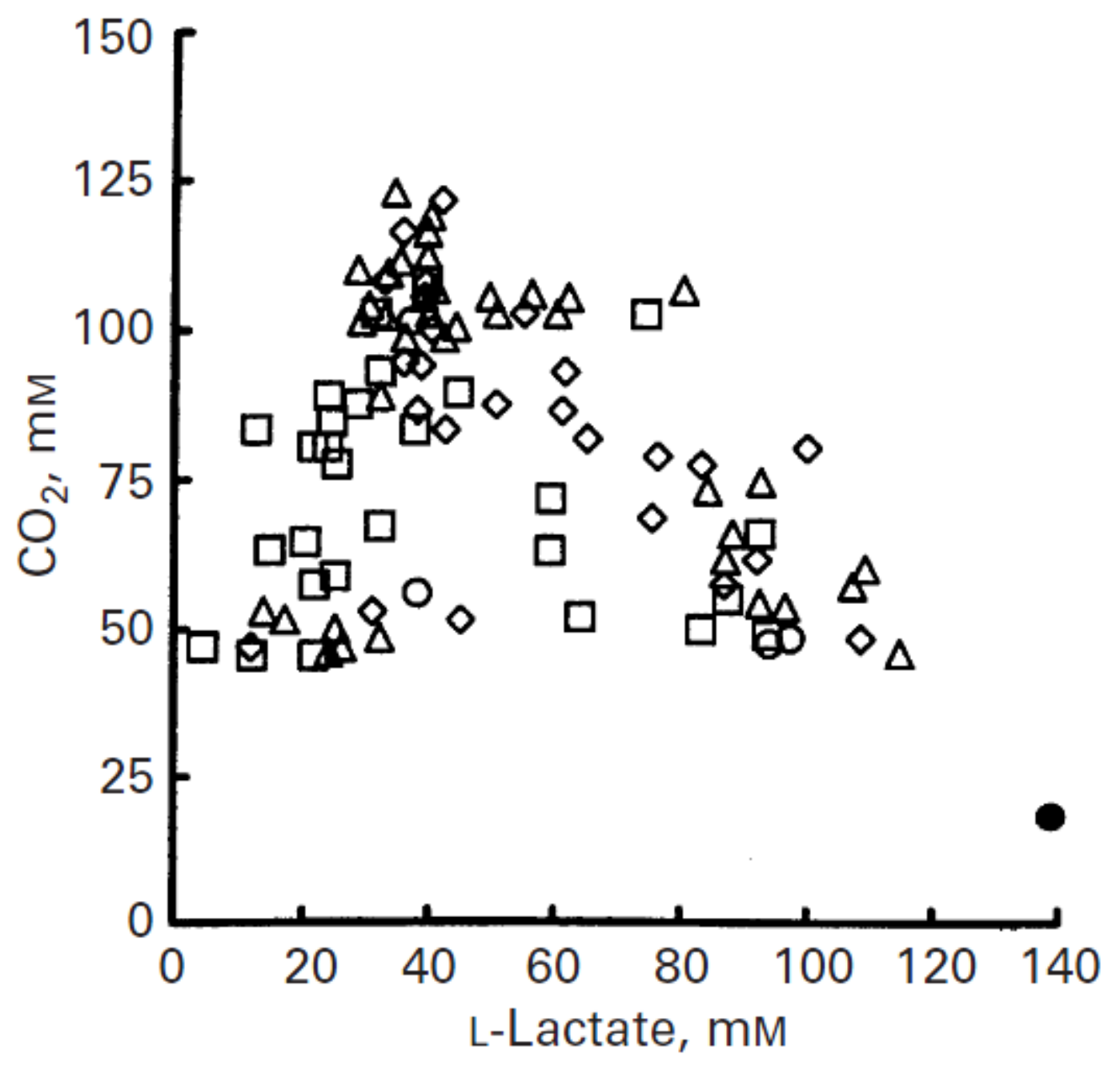


Fig. 3

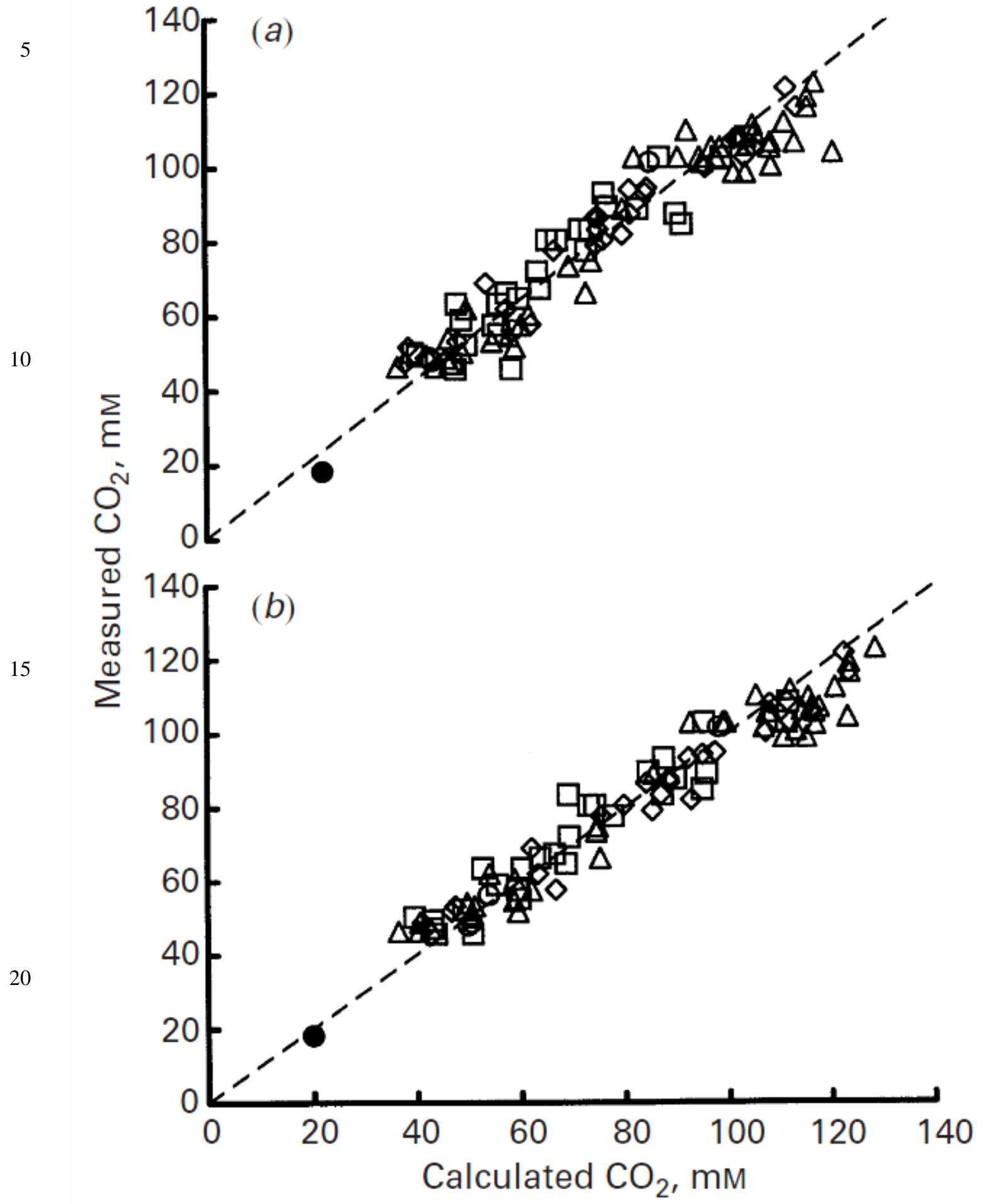


Fig. 4

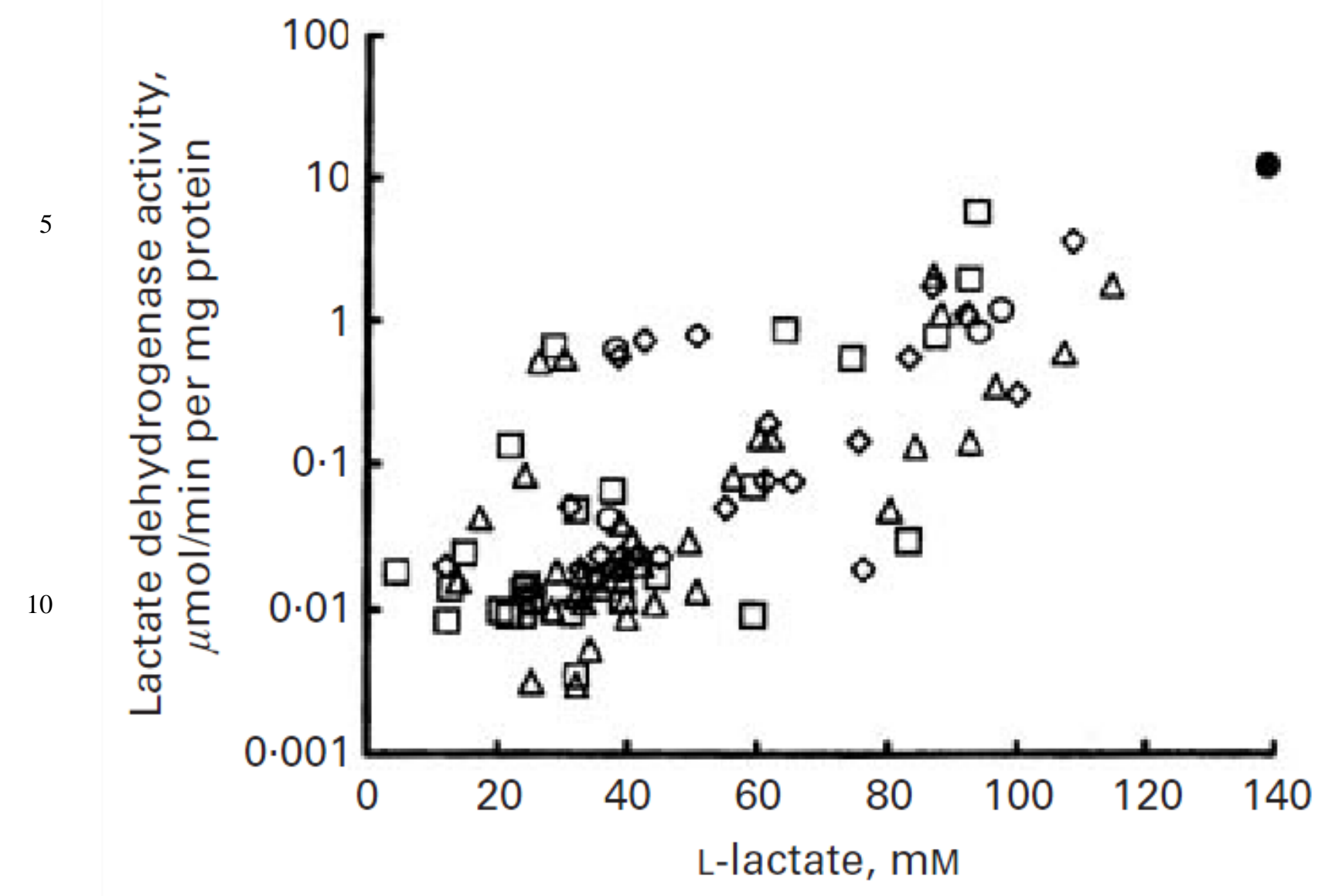


Fig. 5

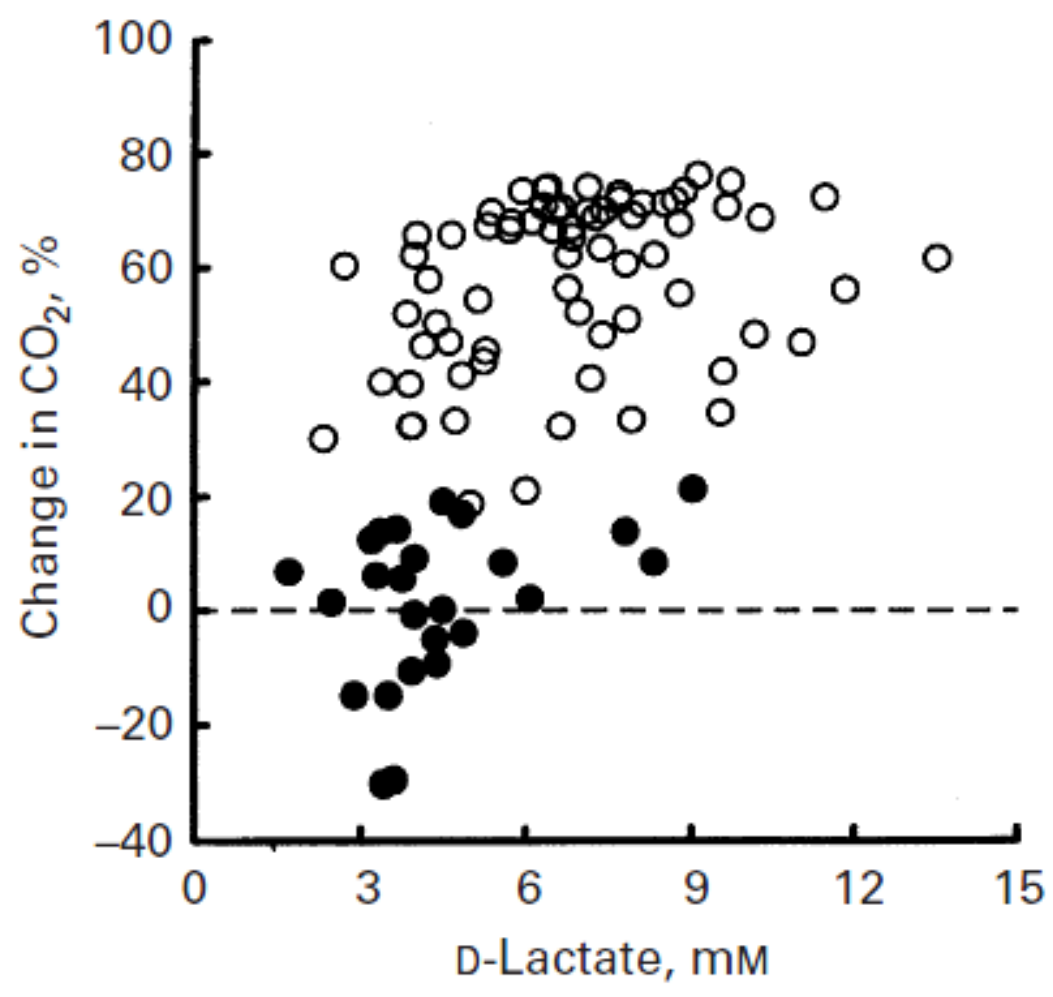


Table 1. Consumption of substrates and production of metabolites by the parental strain and the mutants (means per type of mutant $\pm S D$ ) after 24 h of culture in ewes milk

\begin{tabular}{|c|c|c|c|c|}
\hline Parental strain & $\begin{array}{c}\text { Spontaneous } \\
\text { mutants }\end{array}$ & $\begin{array}{l}\text { Mutants with } 20 \\
\mu \mathrm{g} / \mathrm{ml} \text { of } \mathrm{NTG}^{\dagger}\end{array}$ & $\begin{array}{c}\text { Mutants with } \\
200 \mu \mathrm{g} / \mathrm{ml} \text { of } \\
\text { NTG }\end{array}$ & $\begin{array}{l}\text { UV-induced } \\
\text { mutants }\end{array}$ \\
\hline
\end{tabular}

Substrates

consumed, $\mathrm{mM}$

$\begin{array}{lrrrrr}\text { Citrate } & 10.0 & 10.0 \pm 0.04 & 9.5 \pm 1.66 & 9.6 \pm 1.04 & 9.6 \pm 1.99 \\ \text { Lactose } & 39.3 & 33.7 \pm 2.41 & 41.6 \pm 9.33 & 32.5 \pm 7.43 & 38.5 \pm 8.85\end{array}$

Metabolites

produced, $\mathrm{mM}$

$\begin{array}{lrcccc}\text { L-lactate } & 138.9 & 66.7 \pm 33.55 & 52.3 \pm 28.42 & 39.7 \pm 26.28 & 55.6 \pm 24.60 \\ \text { D-lactate } & 1.7 & 6.1 \pm 3.24 & 7.1 \pm 2.44 & 5.2 \pm 2.25 & 5.9 \pm 1.81 \\ \text { Acetate } & 13.6 & 6.7 \pm 5.56 & 5.5 \pm 3.27 & 9.1 \pm 3.89 & 4.4 \pm 3.25 \\ \text { Ethanol } & 0.0 & 21.2 \pm 8.79 & 35.3 \pm 13.46 & 28.9 \pm 9.94 & 31.7 \pm 12.28 \\ \text { Formate } & 0.0 & 19.5 \pm 9.40 & 30.9 \pm 13.68 & 28.3 \pm 12.34 & 29.5 \pm 12.08 \\ \text { Acetoin } & 4.0 & 15.1 \pm 2.93 & 19.7 \pm 7.32 & 18.2 \pm 6.30 & 15.0 \pm 5.32 \\ \text { 2,3-Butanediol } & 0.9 & 11.4 \pm 9.00 & 20.3 \pm 13.75 & 12.3 \pm 9.88 & 22.9 \pm 10.36 \\ \mathrm{CO}_{2} & 18.1 & 63.4 \pm 25.58 & 86.5 \pm 25.89 & 72.2 \pm 18.67 & 83.8 \pm 21.51 \\ \text { arbon balance, }{ }^{*} \% & 91.6 & 99.4 \pm 11.17 & 96.9 \pm 7.48 & 97.6 \pm 15.43 & 101.7 \pm 11.97\end{array}$

${ }^{\dagger} \mathrm{NTG}, N$-methyl- $N$ '-nitro- $N$-nitrosoguanidine

$5{ }^{\ddagger}$ Metabolites produced / substrates consumed (expressed as mmoles of carbon) 
Table 2. Stability of mutants during successive transfers ${ }^{\dagger}$

(Values at $T_{1}$ and $T_{20}$ are means per type of mutant $\pm S D$ )

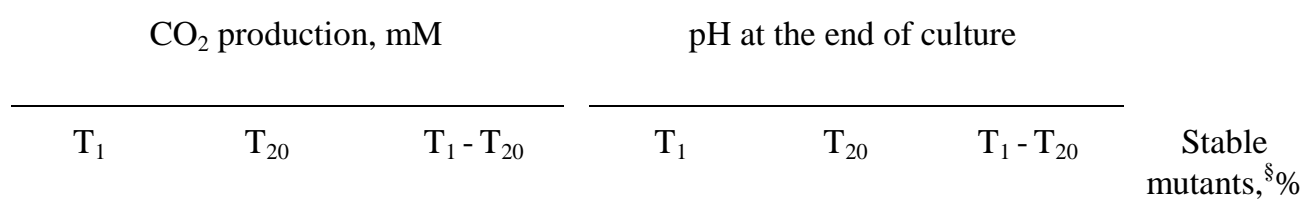

$\begin{array}{lccccccc}\begin{array}{l}\text { Spontaneous } \\ \text { mutants }\end{array} & 63 \pm 25.6 & 46 \pm 19.0 & 17 & 4.6 \pm 0.32 & 4.5 \pm 0.14 & 0.1 & 50 \\ \begin{array}{l}\text { Mutants with } 20 \\ \mu \mathrm{g} / \mathrm{ml} \text { of NTG }\end{array} & 87 \pm 25.9 & 40 \pm 20.5 & 47 & 4.9 \pm 0.24 & 4.6 \pm 0.19 & 0.3 & 18 \\ \begin{array}{l}\text { Mutants with } 200 \\ \mu \mathrm{g} / \mathrm{ml} \text { of NTG }\end{array} & 72 \pm 18.7 & 47 \pm 22.2 & 25 & 5.1 \pm 0.24 & 4.8 \pm 0.26 & 0.3 & 39 \\ \begin{array}{l}\text { UV-induced } \\ \text { mutants }\end{array} & 84 \pm 21.5 & 42 \pm 17.4 & 42 & 4.6 \pm 0.16 & 4.5 \pm 0.24 & 0.1 & 20\end{array}$

${ }^{\dagger} \mathrm{CO}_{2}$ production and $\mathrm{pH}$ values were measured in cultures in milk inoculated with the first

$5 \quad\left(\mathrm{~T}_{1}\right)$ and $20^{\text {th }}\left(\mathrm{T}_{20}\right)$ preculture transfer

${ }^{\ddagger} \mathrm{NTG}, N$-methyl- $N$ '-nitro- $N$-nitrosoguanidine

${ }^{\S}$ Mutants were considered as stable if their $\mathrm{CO}_{2}$ production after the $20^{\text {th }}$ transfer was higher than $80 \%$ of their production after the first transfer, and if no white colonies appeared on LDHA-20 agar (defined in text) 
Table 3. Comparison of the production of metabolites by stable and unstable mutants ${ }^{\dagger}$

$$
\text { mutants }{ }^{\dagger}
$$

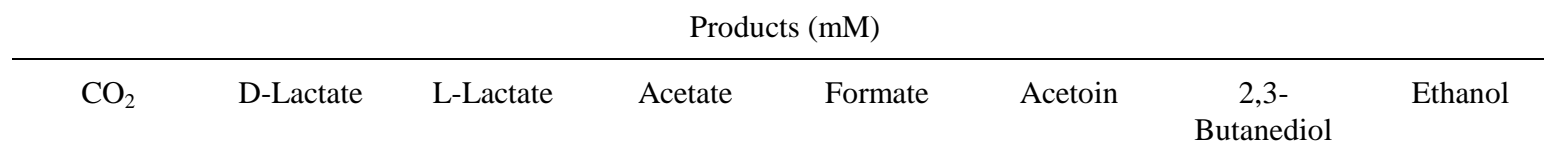

$\begin{array}{lcccccccc}\begin{array}{l}\text { Stable } \\ \text { mutants }\end{array} & 73.8 \pm 22.85 & 4.4 \pm 1.76 & 65.8 \pm 31.76 & 6.7 \pm 4.14 & 21.5 \pm 12.09 & 14.6 \pm 6.14 & 17.1 \pm 13.33 & 24.2 \pm 11.02 \\ \begin{array}{l}\text { Unstable } \\ \text { mutants }\end{array} & 83.0 \pm 23.44 & 6.8 \pm 2.27 & 44.4 \pm 23.74 & 6.2 \pm 3.95 & 32.1 \pm 11.89 & 19 \pm 6.44 & 18.7 \pm 12.04 & 34.6 \pm 11.69 \\ \begin{array}{l}\text { Difference } \\ \text { (11.4) }\end{array} & 9.2 & 2.4 & -21.4 & -0.5 & 10.6 & 4.4 & 1.6 & 10.4 \\ & (38.3) & (-42.7) & (-7.9) & (36.0) & (24.5) & (8.4) & (32.8)\end{array}$

$5 \dagger$ Mean values after the first transfer. Mutants were considered as stable if their $\mathrm{CO}_{2}$ production after the $20^{\text {th }}$ transfer was higher than $80 \%$ of their production after the first transfer, and if no white colonies appeared on LDHA-20 agar (defined in text)

$\$$ Values in parentheses are the differences with respect to the means of all the mutants (percentage) 